\title{
Evaluation of Cytotoxic and Antimicrobial Effects of Two Bt Cry Proteins on a GMO Safety Perspective
}

\author{
Davi Felipe Farias, ${ }^{1}$ Martônio Ponte Viana, ${ }^{1}$ Gustavo Ramos de Oliveira, ${ }^{2,3}$ \\ Magda Aparecida Beneventi, ${ }^{3}$ Bruno Marques Soares, ${ }^{4}$ Claudia Pessoa, ${ }^{4}$ \\ Igor Parra Pessoa, ${ }^{1}$ Luciano Paulino Silva, ${ }^{3}$ Ilka Maria Vasconcelos, ${ }^{1}$ \\ Maria Fátima Grossi de Sá, ${ }^{3,5}$ and Ana Fontenele Urano Carvalho ${ }^{1}$ \\ ${ }^{1}$ Graduate Program in Biochemistry, Federal University of Ceará, 60440-900 Fortaleza, CE, Brazil \\ ${ }^{2}$ Graduate Program in Bioprocess Engineering and Biotechnology, Federal University of Paraná, P.O. Box 19011, \\ 81531-98 Curitiba, PR, Brazil \\ ${ }^{3}$ National Center of Genetic Resources (Embrapa-Cenargen), Parque Estação Biológica-PqEB-Avenida, W5 Norte (Final), \\ P.O. Box 02372, 70770-917 Brasília, DF, Brazil \\ ${ }^{4}$ Graduate Program in Pharmacology, Federal University of Ceará, 60430-270 Fortaleza, CE, Brazil \\ ${ }^{5}$ Graduate Program in Gemonics Sciences and Biotechnology, Catholic University of Brasília, SGAN Quadra 916, Módulo B, \\ W5 Norte, Asa Norte, 70790-160 Brasília, DF, Brazil
}

Correspondence should be addressed to Ana Fontenele Urano Carvalho; aurano@ufc.br

Received 18 April 2014; Accepted 1 July 2014; Published 23 July 2014

Academic Editor: Atanas Atanassov

Copyright (C 2014 Davi Felipe Farias et al. This is an open access article distributed under the Creative Commons Attribution License, which permits unrestricted use, distribution, and reproduction in any medium, provided the original work is properly cited.

Studies have contested the innocuousness of Bacillus thuringiensis (Bt) Cry proteins to mammalian cells as well as to mammals microbiota. Thus, this study aimed to evaluate the cytotoxic and antimicrobial effects of two Cry proteins, Cry8Ka5 (a novel mutant protein) and CrylAc (a widely distributed protein in GM crops). Evaluation of cyto- and genotoxicity in human lymphocytes was performed as well as hemolytic activity coupled with cellular membrane topography analysis in mammal erythrocytes. Effects of Cry8Ka5 and CrylAc upon Artemia sp. nauplii and upon bacteria and yeast growth were assessed. The toxins caused no significant effects on the viability $\left(\mathrm{IC}_{50}>1,000 \mu \mathrm{g} / \mathrm{mL}\right.$ ) or to the cellular DNA integrity of lymphocytes (no effects at $1,000 \mu \mathrm{g} / \mathrm{mL}$ ). The Cry8Ka5 and CrylAc proteins did not cause severe damage to erythrocytes, neither with hemolysis $\left(\mathrm{IC}_{50}>1,000 \mu \mathrm{g} / \mathrm{mL}\right) \mathrm{nor}$ with alterations in the membrane. Likewise, the Cry8Ka5 and CrylAc proteins presented high $\mathrm{LC}_{50}(755.11$ and $>1,000 \mu \mathrm{g} / \mathrm{mL}$, resp.) on the brine shrimp lethality assay and showed no growth inhibition of the microorganisms tested (MIC $>1,000 \mu \mathrm{g} / \mathrm{mL}$ ). This study contributed with valuable information on the effects of Cry8Ka5 and CrylAc proteins on nontarget organisms, which reinforce their potential for safe biotechnological applications.

\section{Introduction}

In the latest years, advances in genetic engineering led to the development of plants that present resistance to insects through expression of cry genes from Bacillus thuringiensis $(B t)$, a soil Gram-positive bacteria. Various plant species, particularly those of economic relevance, such as corn, cotton, potato, tobacco, tomato, and sugar cane, have been genetically modified to express Cry proteins [1-3]. Among these proteins, CrylAc was one of the first to be used for the development of Bt cultures. Many of these CrylAc Bt crops are still available in the biotech seed market $[2,4,5]$.

Recently, it has been engineered the Cry8Ka5 mutant protein which is active against the cotton boll weevil ( $A$. grandis), the main pest of Brazilian cotton culture. This new protein was obtained by in vitro directed molecular evolution technology, DNA shuffling, applied to the cry8Kal gene cloned from the Brazilian Bt strain S811 [6]. Due to its promising activity, Cry8Ka5 is a potential candidate to develop a cotton resistant to A. grandis attack. However, biopesticides, 
including recombinant proteins, must be rigorously tested for their safety for humans and animals [7] and their effects upon nontarget organisms must be thoroughly verified $[8,9]$.

It has been widely reported by scientific literature that $B t$ Cry toxins do not cause adverse effects to mammalian cells, since they do not possess specific receptors for Cry proteins binding [10-12]. On the other hand, studies have contested the innocuous nature of these proteins and some equivalent receptors have also been described to mammalian cells [13, 14]. Furthermore, it is widely known the antimicrobial property of Bt Cry toxins, which raises a concern about the effects of these proteins upon the microbiota of mammals gastrointestinal tract, whether monogastric or ruminants [15-17]. Therefore, given the extensive development and increasing use of GM cultures, including edible plant species expressing $B t$ Cry proteins, new complementary or alternative viable methods, especially those in vitro, for safety assessment of GM foods $[18,19]$.

In order to contribute with safety additional information of CrylAc and Cry8Ka5 toxins on nontarget organisms, this study aimed to evaluate those two entomotoxins for the presence of cytotoxic and antimicrobial effects. Among the cytotoxicity tests, evaluation of cytotoxicity and genotoxicity in human peripheral lymphocytes and hemolytic activity assay of mouse, rabbit, and human (types $\mathrm{A}, \mathrm{B}, \mathrm{AB}$, and $\mathrm{O}$ ) erythrocytes, coupled with cellular membrane topography analysis performed by atomic force microscopy (AFM), have been run. As an alternative and broadly used test in screenings for cytotoxic compounds, the effects of Cry8Ka5 and CrylAc on the survival of Artemia sp. nauplii were also assessed. Finally, we evaluated the effects of these proteins on bacteria and yeast growth in liquid medium.

\section{Materials and Methods}

2.1. Protein Production and Characterization. The Cry $8 \mathrm{Ka} 5$ protein (approximate molecular mass of $73 \mathrm{kDa}$ ) was obtained through the expression of the cry $8 \mathrm{Ka} 5$ gene in E. coli BL21 (DE3) containing the mutant gene inserted into PET101/D TOPO plasmid (Invitrogen) as described by Oliveira et al. [6]. The CrylAc protein was firstly obtained as a protoxin (approximate molecular mass of $130 \mathrm{kDa}$ ) through heterologous expression in E. coli JM109 (Promega) transformed with the recombinant plasmid pKK (Amershan) containing the $c r y 1 A c$ gene of the Bt var. kurstaki HD73 (data not published). Cells were grown in liquid LB medium containing ampicillin $(1 \mu \mathrm{g} / \mathrm{mL})$ at $37^{\circ} \mathrm{C}$, under continuous stirring at $175 \mathrm{rpm}$. To induce expression, $1 \mathrm{mM}$ IPTG was applied to the culture when the $\mathrm{OD}_{600}$ reached 0.8 . After $72 \mathrm{~h}$ of induction, cells were collected by centrifugation $(4,500 \times g$, for $20 \mathrm{~min}$, at $10^{\circ} \mathrm{C}$ ) and the pellet was resuspended in lysis buffer (sucrose $15 \%$, lysozyme $2 \mathrm{mg} / \mathrm{mL}$, EDTA $50 \mathrm{mM}$, Tris $\mathrm{HCl} 50 \mathrm{mM}, \mathrm{pH} 8.0$ ) for $12 \mathrm{~h}$, at $4^{\circ} \mathrm{C}$. The cell suspension was sonicated on ice ( 5 cycles of $300 \mathrm{~s}$ at $70 \%$ ) and centrifuged for $10,000 \times g$, for $15 \mathrm{~min}$, at $4^{\circ} \mathrm{C}$. The pellet was then washed by centrifugation $\left(10,000 \times g\right.$, for $30 \mathrm{~min}$, at $\left.4^{\circ} \mathrm{C}\right)$ three times in $30 \mathrm{~mL}$ of $0.5 \mathrm{M} \mathrm{NaCl}$ solution containing $2 \%$ Triton X-100, five times in $30 \mathrm{~mL}$ of $\mathrm{NaCl} 0.5 \mathrm{M}$ and twice with $30 \mathrm{~mL}$ of distilled water. Then, the inclusion bodies containing the CrylAc protoxin were solubilized in solubilization buffer (10 mM DTT, $50 \mathrm{mM}$ sodium carbonate, and $\mathrm{pH} 10.5)$ for $2 \mathrm{~h}$, at $37^{\circ} \mathrm{C}$, and dialyzed against water in a $12 \mathrm{kDa}$ dialysis membrane. The protoxin was activated with trypsin 1:50 $(\mathrm{w} / \mathrm{w})$ for $18 \mathrm{~h}$, at $37^{\circ} \mathrm{C}$. The proteolysis was stopped with $1 \mathrm{mM}$ PMSF. The material containing the active toxin CrylAc (approximate molecular mass of $65 \mathrm{kDa}$ ) was again dialyzed with $12 \mathrm{kDa}$ dialysis membrane against distilled water for $24 \mathrm{~h}$.

The production of both proteins was monitored through quantification of soluble proteins by the Bradford method [20], using a curve constructed with bovine serum albumin as standard. Besides, the purity of Cry $8 \mathrm{Ka} 5$ and CrylAc and activation of the last one were monitored by $12.5 \%$ SDS-PAGE [21].

From the SDS-PAGE gels of Cry8Ka5 and CrylAc the relative percentage of purity of both proteins was calculated using the Image Master 2D platinum (v.7.0, GE Healthcare) software. This methodology has been successfully adopted by our research team, and it is also widely used by chemical companies to show the purity of the commercialized proteins.

Before the use in the cytotoxic, genotoxic, and antimicrobial tests, both proteins were also checked for their bioactivity against their respective target insects. The Cry8Ka5 protein was tested against $A$. grandis larvae according to the methodology described by Oliveira et al. [6] and the CrylAc against Spodoptera frugiperda larvae following the method described by Grossi-de-Sa et al. [22].

2.2. N-Terminal Sequence Determination. To confirm the identity of the proteins obtained, the $\mathrm{N}$-terminal amino acid sequences of the Cry8Ka5 and CrylAc proteins were determined on a Shimadzu PPSQ-10 automated protein sequencer (Kyoto, Japan) performing Edman degradation [23]. The sequences were determined from protein blotted on polyvinylidene fluoride (PVDF) after Tricine-SDS-PAGE. Phenylthiohydantoin (PTH) amino acids were detected at $269 \mathrm{~nm}$ after separation on a reverse phase C18 column $(4.6 \mathrm{~mm} \times 2.5 \mathrm{~mm})$ under isocratic conditions, according to the manufacturer's instructions. The sequences obtained were compared with available amino acids sequences at UniProtKB database (http://www.uniprot.org/) using the FASTA3 search program. In addition, the sequences were then aligned in the Uniprot platform (http://www.uniprot.org/) to the complete sequences of Cry $8 \mathrm{Ka} 5$ and CrylAc previously determined by our group.

\subsection{Evaluation of Cyto- and Genotoxicity in Human Lymphocytes}

2.3.1. Peripheral Blood Collection and Isolation of the Peripheral Blood Mononuclear Cells. Peripheral blood sampling was performed using sterile disposable $10 \mathrm{~mL}$ syringe or safety needle (BD vacutainer). To this end, three healthy adult volunteers were chosen, of either sex, aged 20-30 years, with no history of recent illness, no smoking, and no recent exposure to radiation, drug, or alcohol [24]. 
The peripheral blood mononuclear cells were isolated from a sample of $3 \mathrm{~mL}$ peripheral blood plus $5 \mathrm{~mL}$ of $50 \mathrm{mM}$ sodium phosphate buffer, $\mathrm{pH}$ 7.5. This mixture was added to a graduated tube with $2 \mathrm{~mL}$ of Ficoll and subjected to centrifugation at $2,000 \times \mathrm{g}$, for $30 \mathrm{~min}$, at $25^{\circ} \mathrm{C}$. Then, the intermediate region between the red cells and serum, called "lymphocytes cloud," was aspirated and transferred to a third tube. Subsequently, it was filled with $50 \mathrm{mM}$ sodium phosphate buffer, $\mathrm{pH} 7.5$, to a final volume of $11 \mathrm{~mL}$, and the tube was centrifuged at $108 \times \mathrm{g}$, for $20 \mathrm{~min}$, at $25^{\circ} \mathrm{C}$. The supernatant was discarded and the pellet of lymphocytes was resuspended in $2 \mathrm{~mL}$ of $50 \mathrm{mM}$ sodium phosphate buffer, $\mathrm{pH}$ 7.5 .

2.3.2. Cytotoxic Activity in Human Lymphocytes. The evaluation of the cytotoxic potential of the Cry8Ka5 and CrylAc proteins in human lymphocytes was determined by the MTT [3-(4,5-dimethylthiazol-2-yl)-2,5-diphenyltetrazolium bromide] method as described by Mosmann [25]. The lymphocytes obtained from healthy individuals were cultured in 96-well microplates at a density of $2 \times 10^{6}$ cells $/ \mathrm{mL}$. After $24 \mathrm{~h}$ of the culture starting point, lymphocytes were exposed for $72 \mathrm{~h}$ to the proteins at concentrations ranging from 1.5 to $1,000 \mathrm{mg} / \mathrm{mL}$. A $20 \mathrm{mM}$ sodium phosphate buffer, $\mathrm{pH}$ 7.0, was used as negative control and doxorubicin $(0.6 \mathrm{mM})$ was used as positive control. After the incubation period, the plates were centrifuged at $15 \times g$, for $15 \mathrm{~min}$, at $25^{\circ} \mathrm{C}$, and the supernatant was discarded. Each well received $200 \mu \mathrm{L}$ of MTT solution (10\% in RPMI 1640) and was reincubated for $3 \mathrm{~h}$, at $37^{\circ} \mathrm{C}$, under controlled atmosphere of $5 \% \mathrm{CO}_{2}$. After this period, the plates were again centrifuged $(30 \times g$, for $10 \mathrm{~min}$, at $25^{\circ} \mathrm{C}$ ), the supernatant was discarded, and the precipitate was resuspended in $150 \mu \mathrm{L}$ of DMSO. To quantify the reduced salt in living cells, the absorbance was measured with the aid of a microplate spectrophotometer at a wavelength of $550 \mathrm{~nm}$. $\mathrm{IC}_{50}$ values (inhibitory concentration of $50 \%$ of cells) and confidence interval (CI of 95\%) were calculated by nonlinear regression analysis. Significant differences between means were calculated by analysis of variance (ANOVA) followed by Student-Newman-Keuls $(P<0.05)$, using appropriate statistical software.

2.3.3. Genotoxicity Activity in Human Lymphocytes. The comet assay, also known as single cell gel electrophoresis (SCGE), has been routinely used in the study of the genotoxic potential of industrial chemicals, biocides, agrochemicals, and pharmaceuticals. According to the protocol described by Lima et al. [27], lymphocytes obtained from healthy individuals $\left(5.0 \times 10^{4}\right.$ cells $\left./ \mathrm{mL}\right)$ were cultured in the presence of increasing concentrations $(100,500$, and $1,000 \mu \mathrm{g} / \mathrm{mL})$ of both proteins, Cry $8 \mathrm{Ka} 5$ and CrylAc, for $24 \mathrm{~h}$, at $37^{\circ} \mathrm{C}$, in an atmosphere of $5 \% \mathrm{CO}_{2}$. A $20 \mathrm{mM}$ sodium phosphate buffer, $\mathrm{pH}$ 7.0, was used as negative control and doxorubicin $(0.6 \mathrm{mM})$ as positive control. After treatment, cells were subjected to agarose gel electrophoresis $(25 \mathrm{~V}, 300 \mathrm{~mA})$ for $20 \mathrm{~min}$. For staining the gel slides, a solution of ethidium bromide $(20 \mathrm{mg} / \mathrm{mL})$ was used. The slides were analyzed with the aid of a fluorescence microscope (Olympus, model
BX41, Shinjuku, Tokyo, Japan). The analysis was performed according to the standard scores previously determined by the size and intensity of the comet tail. One hundred comets were counted and classified per slide by visual analysis. The results were organized in five categories $(0,1,2,3$, and 4$)$ that represent the percentage of DNA in the comet tail, which in turn indicates the degree of injury suffered by the cell. The damage index (DI) was calculated by the following formula:

$$
\mathrm{DI}=\sum_{i=0}^{4} n_{i} \times i,
$$

where $n_{i}$ is the number of cells with the degree of injury $i(0$, $1,2,3$, or 4 ).

Thus, DI values can range from 0 (no injury) to 4 (maximum injury). For statistical analysis, significant differences between means were calculated by analysis of variance (ANOVA) followed by Student-Newman-Keuls $(P<0.05)$, using suitable statistical software.

\subsection{Hemolytic Activity in Erythrocytes of Humans and Laboratory Animals}

2.4.1. Human Donors. The human blood of A, B, AB, and $\mathrm{O}$ blood types was obtained from adult volunteer donors, three volunteers for each blood type of any gender, 20-30 years, in healthy conditions as described in Section 2.3.1.

All procedures involving humans were submitted for approval by the Ethics Committee on Human Research of the Federal University of Ceará (Fortaleza, Brazil) to be conducted in accordance with Resolution 196/96 of the National Health Council.

2.4.2. Laboratory Animals. One male California rabbit with three months of age was purchased from the Cuniculture Division of the Federal University of Ceará (Fortaleza, Brazil). The rabbit was maintained in the Biochemistry and Molecular Biology Department, at the same Institution, with water and food (Biobase, São Paulo, Brazil) ad libitum.

Three female Wistar rats with three weeks of age were obtained from the Animal Facilities of the Federal University of Ceará (Fortaleza, Brazil). The animals were housed in the Department of Biology, at the same University, with temperature $23.0 \pm 2.0^{\circ} \mathrm{C}$, photoperiod $(12 \mathrm{~h}$ dark $/ 12 \mathrm{~h}$ light $)$ and humidity (45-55\%) controlled. The rats were kept in adequate numbers in boxes of polypropylene with substrate of pine wood shavings. Water and food were offered ad libitum until the approximate weight of $120 \mathrm{~g}$ for blood sampling is reached.

All protocols with animals adopted in this work were submitted for approval by the Ethics Committee on Animal Research of the Federal University of Ceará (Fortaleza, Brazil), that follows the principles of the Brazilian College of Animal Experimentation and obeys the Law $\mathrm{N}^{\circ} 11.794$ of 8 October 2008 (Lei Arouca), which regulates the use of animals in scientific research.

2.4.3. Blood Sampling. The human blood was collected from the antecubital area of the arm using sterile disposable $10 \mathrm{~mL}$ 
syringe or safety needle, and transferred to heparinized tubes, slowly homogenized and stored at $4^{\circ} \mathrm{C}$ until the time of isolation of erythrocytes.

The rabbit blood was collected from a small cross-section in the marginal ear vein with a scalpel. The blood was collected in heparinized tube, homogenized, and conditioned at $4^{\circ} \mathrm{C}$ until the isolation of erythrocytes. To sample mice blood, the animals were slightly sedated with halothane (Zeneca, São Paulo, Brazil), and blood was collected by puncturing the retro-orbital plexus with a glass microhematocrit tubes. Blood was collected in heparinized microtubes, homogenized, and maintained at $4^{\circ} \mathrm{C}$.

A portion of the human type $\mathrm{O}$ blood was set aside for cell membrane topography analysis, while the other part was intended for isolation of erythrocytes. All other blood samples were destined only to isolation of the erythrocytes. Then, for the isolation of erythrocytes and preparation of a suspension at $2 \%$, all blood samples were centrifuged at 200 $\times g$, for $10 \mathrm{~min}$, at $25^{\circ} \mathrm{C}$. The supernatant was discarded and from the precipitate was removed $2 \mathrm{~mL}$, which was mixed with $100 \mathrm{~mL}$ of $0.9 \% \mathrm{NaCl}$. The suspension was slightly mixed and packed at $4^{\circ} \mathrm{C}$ for no more than $24 \mathrm{~h}$.

2.4.4. Hemolytic Activity. The hemolytic activity of the entomotoxins was investigated following the methodology described by Merker and Levine [28] and Bernheimer [29], with some modifications. The presence of hemolysis in rat, rabbit, and human (types $\mathrm{A}, \mathrm{B}, \mathrm{AB}$, and $\mathrm{O}$ ) erythrocytes suspensions at $2 \%$ was observed after incubation for $1 \mathrm{~h}$ $\left(30 \mathrm{~min}\right.$ at $37^{\circ} \mathrm{C}$ and then $30 \mathrm{~min}$ at $25^{\circ} \mathrm{C}$ ) with increasing concentrations of Cry8Ka5 and CrylAc proteins, ranging from 7.8 to $1,000 \mu \mathrm{g} / \mathrm{mL}$ in a ratio of $1: 2(\mathrm{v} / \mathrm{v})$. Bovine serum albumin was used as control in the same conditions. The degree of hemolysis was calculated by measuring the release of hemoglobin at a wavelength of $540 \mathrm{~nm}$ after centrifuging the mixture at $1,000 \times g$, for $5 \mathrm{~min}$, at $25^{\circ} \mathrm{C}$. The complete lysis $(100 \%)$ was obtained by diluting $200 \mu \mathrm{L}$ of the $2 \%$ cell suspension in $200 \mu \mathrm{L}$ of distilled water, and no lysis (negative control) was obtained with the same proportion of cells in saline solution. Hemolytic activity was calculated according to the following formula:

$\left[\left(\mathrm{Abs}_{540}\right.\right.$ of the sample $)-\left(\mathrm{Abs}_{540}\right.$ of the negative control $\left.)\right]$

$$
\times \frac{100}{\mathrm{Abs}_{540} \text { of the positive control }} \text {. }
$$

$\mathrm{IC}_{50}$ values (concentration causing $50 \%$ hemolysis of the cells) and confidence interval (CI of 95\%) were calculated by analysis of nonlinear regression. Significant differences between means were calculated by analysis of variance (ANOVA) followed by Student-Newman-Keuls $(P<0.05)$, using proper statistical software.

2.5. Analysis of the Cellular Membrane Topography by AFM. To assess any effects of the Cry8Ka5 and CrylAc proteins on erythrocytes which do not necessarily trigger hemolysis, data from cellular membrane topography obtained by
AFM were analyzed to provide additional information to the classical hemolytic activity assay. For that, it was used human whole blood $\mathrm{O}$ type treated with Cry8Ka5 or CrylAc $(1,000 \mu \mathrm{g} / \mathrm{mL})$ for $30 \mathrm{~min}$ at $37^{\circ} \mathrm{C}$ and then for $30 \mathrm{~min}$ at $25^{\circ} \mathrm{C}$. For comparison purposes, the cells were also treated with BSA $(1,000 \mu \mathrm{g} / \mathrm{mL})$ or were just untreated. Then, we prepared blood films on slides fixed with methanol and allowed them to air dry, for all treatments (three slides per treatment).

The images were obtained in the constant contact force mode using cantilevers of $200 \mu \mathrm{m}$ in "V" shape (spring constant value of $\gg 0.15 \mathrm{~N} / \mathrm{m}$ and resonance frequency of $24 \mathrm{kHz}$ ) and integrated pyramidal tip (radius of curvature $<20 \mathrm{~nm}$ ). The movement of the scanner was $100 \mu \mathrm{m}$ in $X Y$ directions and $7 \mu \mathrm{m}$ in the direction $Z$. All images were acquired as $512 \times 512$ pixels at a scanning rate of $1 \mathrm{~Hz}$. The images were processed by the software Particle Analysis SPM9600 (Shimadzu, Tokyo, Japan). The process consisted of an automatic levelling Wt surface. One hundred individual cells from each treatment were manually segmented using the function of markup analysis program, followed by the cell measurements. The parameters selected for the measurements were (1) perimeter, which obtains the contour length of a particle and the default width obtained by measuring the distance between two parallel lines which are tangent to a particle; (2) average $Z$, which obtains the average value data from the $Z$ pixels that form a particle; (3) area excluding voids which provides an area using the equation: Area excluding voids $=($ area per pixel $) \times($ number of pixels of a particle $)$; (4) area including voids which provides an area using the equation: area including voids $=($ area per pixel $) \times[$ (number of pixels of a particle) + (number of pixels in the void of a particle)]; (5) surface area (the calculation uses imaginary structures where the points of the structure are created from $Z$ values spatially arranged from pixels that form a particle, and quadrangles formed with the points of the structures are divided into two to create triangles; then, the sum of the areas of these triangles is calculated); and (6) volume which is obtained by the following equation: volume = area excluding voids $\times$ average of $Z$ value.

2.5.1. AFM Data Analysis. The parameters processed by the software Particle Analysis SPM-9600 (Shimadzu, Japan) were subjected to one-way ANOVA statistical analysis, and the means were compared by Sidak multiple comparisons $(P<$ $0.05)$, using the appropriate statistical program.

\subsection{Effects on Artemia sp.}

2.6.1. Artemia Nauplii. Cysts of brine shrimp were purchased from aquarium shops of the Fortaleza city (Ceará, Brazil). To obtain brine shrimp nauplii, a small portion of cysts was placed to hatch in $2 \mathrm{~L}$ of artificial seawater $(15.15 \mathrm{~g} \mathrm{NaCl}+$ $2.98 \mathrm{~g} \mathrm{MgCl}_{2} \cdot 6 \mathrm{H}_{2} \mathrm{O}+2.86 \mathrm{~g} \mathrm{MgSO}_{4} \cdot 7 \mathrm{H}_{2} \mathrm{O}+0.65 \mathrm{~g} \mathrm{CaCl}_{2}+$ $0.116 \mathrm{~g} \mathrm{NaHCO}_{3}+0.414 \mathrm{~g} \mathrm{KCl}$, in $1 \mathrm{~L}$ of dechlorinated distilled water), under constant artificial illumination until $48 \mathrm{~h}$ before the beginning of the experiment. No food was administered during this period. 
2.6.2. Cytotoxicity Activity towards Artemia sp. The effects of Cry8Ka5 and CrylAc proteins at concentrations ranging from 3.9 to $1,000 \mu \mathrm{g} / \mathrm{mL}$ on the survival rate of Artemia sp. were analyzed. The brine shrimp lethality assay is proposed as an alternative model for evaluation of cytotoxicity [30]. Brine shrimp nauplii ( $n=10 /$ sample/concentration) hatched in artificial seawater (salinity of 3.5\%) and after $48 \mathrm{~h}$ they were transferred to a $3.0 \mathrm{~mL}$ volume of each sample at different concentrations. The samples were previously prepared in seawater. Negative controls were prepared using just seawater or seawater containing BSA at $1,000 \mu \mathrm{g} / \mathrm{mL}$.

After $24 \mathrm{~h}$, the dead nauplii were counted at each concentration of the samples and plotted on a graph to correlate mortality $\times$ sample concentration, to calculate the lethal concentration for $50 \%$ of individuals $\left(\mathrm{LC}_{50}\right)$ by Probit analysis [31].

\subsection{Effects on Microorganisms}

2.7.1. Microorganisms. Two strains of Gram-positive bacteria, Bacillus subtilis ATCC 6633 and Staphylococcus aureus ATCC 25923, and two strains of Gram-negative, Enterobacter aerogenes ATCC 13048 and Salmonella choleraesuis ATCC 10708, were provided by the Laboratory of Microbial Ecology and Biotechnology from the Federal University of Ceará (Fortaleza, Brazil) and were initially purchased from ATCC (American Type Culture Collection, Manassas, VA, USA). The yeast Candida albicans, C. tropicalis, and Pichia anomala were obtained, identified, isolated, and maintained in the same Laboratory, while Saccharomyces cerevisiae was obtained commercially in the form of yeast bread in Fortaleza city (Ceará, Brazil).

2.7.2. Antimicrobial Activity. In order to investigate the potential effects of Cry8Ka5 and CrylAc proteins on common gastrointestinal microbiota of mammals or phylogenetically close to that, growth inhibitory activity of bacterial and fungal was performed in liquid medium.

The study of growth inhibitory activity of bacteria exposed to concentrations of Cry8Ka5 and CrylAc ranging from 30.6 to $1,000 \mu \mathrm{g} / \mathrm{mL}$ protein was performed according to the protocol described by Hissa et al. [32]. In sterile conditions, to each well of the microtiter plate was added $100 \mu \mathrm{L}$ of nutrient broth containing bacterial cells at a concentration of $10^{7} \mathrm{CFU} / \mathrm{mL}$, followed by $100 \mu \mathrm{L}$ of each sterilized sample (sterilized using a Millipore filter of pore size $0.22 \mu \mathrm{M})$ and ovalbumin at a concentration of $2,000 \mu \mathrm{g} / \mathrm{mL}$ (non-Cry control), $50 \mathrm{mM}$ sodium phosphate buffer $\mathrm{pH}$ 7.0 (negative control), or $0.4 \%$ formol (positive control). Then, the microtiter plates were subjected to reading at a wavelength of $600 \mathrm{~nm}$ in a microplate reader, followed by new readings every $4 \mathrm{~h}$, up to a total of $24 \mathrm{~h}$. For each sample, a triplicate against each bacteria species was performed. From the sample dilutions proceeded to calculate the minimum inhibitory concentration (MIC).

The growth inhibition assay of C. albicans, C. tropicalis, $P$. anomala, and S. cerevisiae by Cry8Ka5 and CrylAc proteins, in concentrations ranging from 30.6 to $1,000 \mu \mathrm{g} / \mathrm{mL}$, was performed according to the methodology described by Ribeiro et al. [33], with some modifications.

In microtitration plates (sterile) were added to each well $100 \mu \mathrm{L}$ of BHI broth ( $\mathrm{pH}$ adjusted to 5.0) with a concentration of yeast-like cells corresponding to a reading of 0.05 $\left(\mathrm{OD}_{600}\right)$, followed by $100 \mu \mathrm{L}$ of each sample of Cry8Ka5 and CrylAc proteins (sterilized using a Millipore filter of pore size $0.22 \mu \mathrm{M})$, ovalbumin $(2000 \mu \mathrm{g} / \mathrm{mL})$, sodium phosphate buffer $50 \mathrm{mM}$ pH 7.0 (negative control), or $0.4 \%$ formol (positive control). Then, the plates were subjected to the reading at a wavelength of $600 \mathrm{~nm}$ in a microplate reader, followed by further readings every $6 \mathrm{~h}$ until a total of $48 \mathrm{~h}$. To each sample, it was performed one triplicate to each yeast species. From the sample dilutions proceeded to estimate the minimum inhibitory concentration (MIC).

\section{Results}

3.1. Recombinant Proteins Production and Characterization. SDS-PAGE profiles of Cry8Ka5 and CrylAc recombinant proteins, as well as some steps of the expression and purification process, are shown in Figure 1. Both entomotoxins presented the expected molecular mass (near to $70.0 \mathrm{kDa}$ ). From the SDS-PAGE profiles it was possible to estimate the relative purity of each protein obtained using adequate software. Either for Cry8Ka5 or for CrylAc, the different batches of expression and purification presented relative purity which ranged from $75 \%$ up to $95 \%$. Besides, Cry8Ka5 and CrylAc proteins showed to be active against $A$. grandis and $S$. frugiperda larvae, respectively, in the expected magnitude.

To confirm the identity of the proteins produced, they were electrotransferred from the electrophoresis gels to PVDF membranes and carried out for determination of $\mathrm{N}$ terminal sequence. The N-terminal sequence obtained for Cry8Ka5 was SEGYDNKYFANPEVFAAPGGITTGIT, which is identical to the amino acid sequence deposited by the group that developed the mutant protein [6] with accession number G8XRZ1 at UniProtKB/Swiss-Prot database. Likewise, the $\mathrm{N}$-terminal sequence obtained for CrylAc was IETGYTPIDISLSLTQFLLSEFVPGAGF, which is identical to multiple entries for the same protein (P05068, E3TBL1, Q6XLN7).

3.2. Cyto- and Genotoxicity of Cry8Ka5 and CrylAc Proteins. Table 1 shows the results of the evaluation of cytotoxicity in human peripheral lymphocytes of Cry8Ka5 and CrylAc proteins through MTT assay after $72 \mathrm{~h}$ of exposure. This classic assay for assessment of nonspecific cytotoxic effects of natural and synthetic compounds showed that, even at the highest concentration tested $(1,000 \mu \mathrm{g} / \mathrm{mL})$, the toxins caused no significant effect on the viability of the lymphocytes, resulting in $\mathrm{IC}_{50}>1,000 \mu \mathrm{g} / \mathrm{mL}$.

As for the evaluation of genotoxicity, the proteins did not cause relevant cellular DNA damage, since the outcomes were comparable to the result of the negative control, the $20 \mathrm{mM}$ sodium phosphate buffer, $\mathrm{pH} 7.0$ (Figure 2). The positive control, doxorubicin $0.6 \mu \mathrm{M}$, produced DNA damage index higher than 200 . 


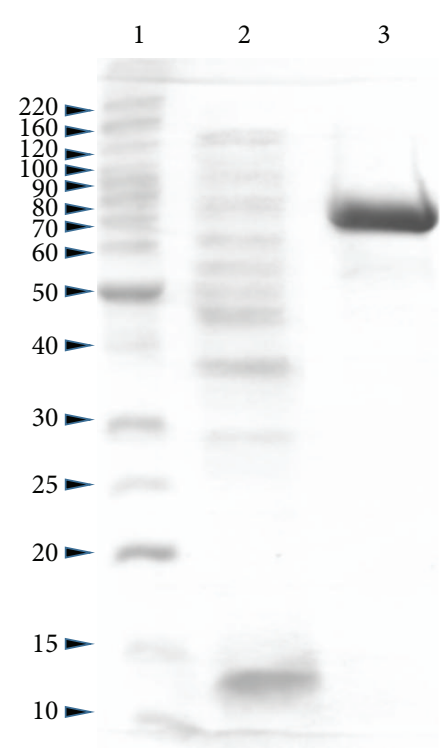

(a)

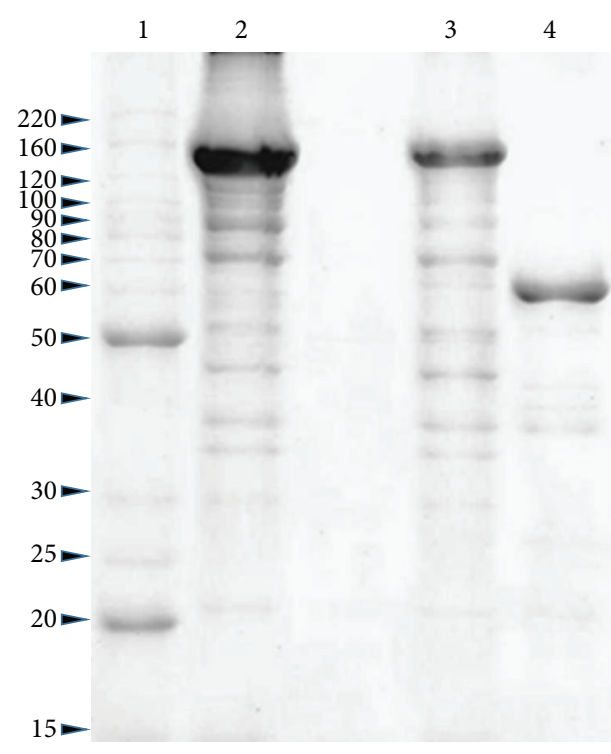

(b)

FiguRE 1: (a) Electrophoretic profile of the heterologous gene expression of Cry8Ka5 protein in polyacrylamide gel (12.5\%) under reducing and denaturing conditions. Lane 1: molecular weight markers. Lane 2: peak not retained from the chromatography on the Ni-NTA resin. Lane 3: peak retained from the chromatography on the Ni-NTA resin eluted with $20 \mathrm{mM}$ imidazole. (b) Electrophoretic profile of the heterologous gene expression of CrylAc protein in polyacrylamide gel (12.5\%) under reducing and denaturing conditions. Lane 1: molecular weight marker; Lane 2: protoxin CrylAc not dialyzed; Lane 3: protoxin CrylAc dialyzed; Lane 4: toxin CrylAc after trypsinization and dialysis.



Figure 2: DNA damage index in human lymphocytes exposed for $24 \mathrm{~h}$ to Cry8Ka5 and CrylAc proteins. The $20 \mathrm{mM}$ sodium phosphate buffer, $\mathrm{pH} 7.0$, was used as negative control and doxorubicin at the concentration of $0.6 \mathrm{mM}$ was used as positive control. 1,2 , and 3 correspond to CrylAc at concentrations of 100,500 , and $1,000 \mu \mathrm{g} / \mathrm{mL}$, respectively. 4,5 , and 6 correspond to Cry8Ka5 at concentrations of 100,500 , and $1,000 \mu \mathrm{g} / \mathrm{mL}$, respectively. All data correspond to means \pm standard deviation of four independent experiments. ${ }^{*} P<0.05$; compared to negative control by ANOVA/Newman-Keuls.

3.3. Hemolytic Activity. In Table 2, you can see the results of the hemolytic activity analysis of $2 \%$ human (types $\mathrm{A}, \mathrm{B}, \mathrm{AB}$, and $\mathrm{O}$ ), rabbit, and mice erythrocyte suspensions treated with Cry8Ka5 and CrylAc. The Cry8Ka5 protein, just like bovine serum albumin, did not show significant hemolytic activity $(<1 \%)$ for all erythrocytes suspensions used. In contrast, the CrylAc toxin showed some hemolytic activity in all tested erythrocyte suspensions, which oscillated from $4.6 \%$ in rabbit
TABLE 1: Cytotoxic activity of Cry8Ka5 and CrylAc proteins on human peripheral lymphocytes evaluated by MTT assay [3-(4,5dimethylthiazol-2-yl)-2,5-difeniltetrazol] after $72 \mathrm{~h}$ exposure.

\begin{tabular}{lc}
\hline Proteins & $\mathrm{IC}_{50}{ }^{\mathrm{a}}$ for human lymphocytes $(\mu \mathrm{g} / \mathrm{mL})$ \\
\hline Cry8Ka5 & $>1,000$ \\
CrylAc & $>1,000$ \\
\hline
\end{tabular}

${ }^{\mathrm{a}}$ Concentration able to inhibit $50 \%$ of human lymphocytes growth.

to $16.6 \%$ in type $\mathrm{AB}$ human erythrocytes suspension. Given the low percentage of hemolysis detected, all samples tested showed $\mathrm{IC}_{50}>1,000 \mu \mathrm{g} / \mathrm{mL}$.

3.4. AFM. In order to contribute with further information to the hemolytic activity test, the cell membrane topography of human erythrocytes (type $\mathrm{O}$, in whole blood after treatment for $1 \mathrm{~h}$, at $37^{\circ} \mathrm{C}$ ) was assessed with Cry8Ka5, CrylAc, and bovine serum albumin proteins at a concentration of $1,000 \mu \mathrm{g} / \mathrm{mL}$ (Table 3 ). Seven parameters were analyzed in total. Almost all parameters of erythrocytes treated with Cry8Ka5 differed $(P<0.05)$ from those of the other treatments, CrylAc, albumin, and erythrocytes untreated. The only exception was the average $Z$ parameter that was equal to that of albumin treated erythrocytes. The average $Z$ obtained the average value data from the $Z$ pixels that form a particle (an erythrocyte). The remaining samples, CrylAc and bovine serum albumin, caused significant differences $(P<0.05)$ in erythrocytes only in the volume parameter when compared to untreated erythrocytes. In Figure 3, there are illustrations in $2 \mathrm{D}$ and $3 \mathrm{D}$ of the erythrocytes treated with 

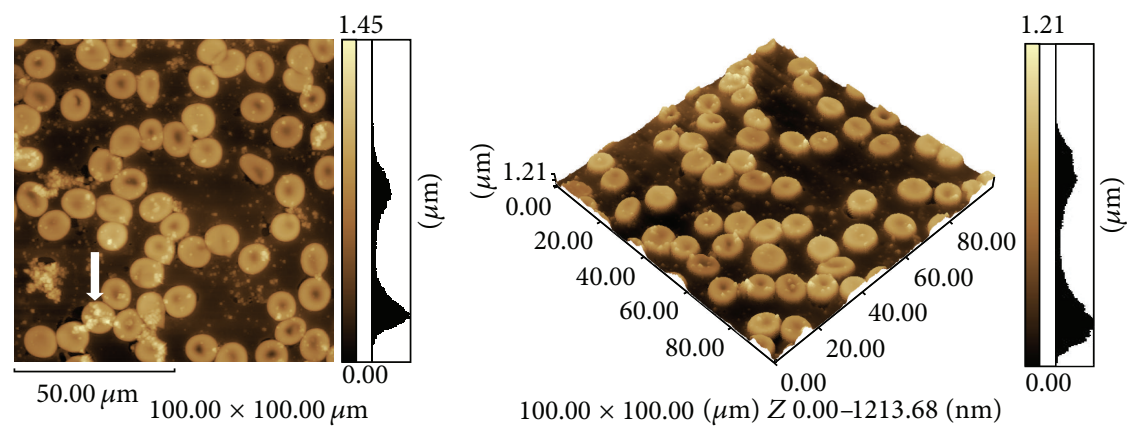

$100.00 \times 100.00(\mu \mathrm{m}) Z \quad 0.00-1213.68(\mathrm{~nm})$

(a)

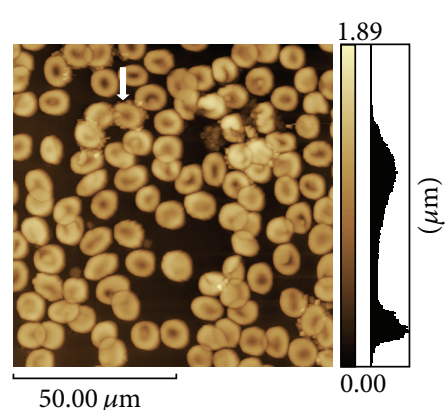

$100.00 \times 100.00 \mu \mathrm{m}$

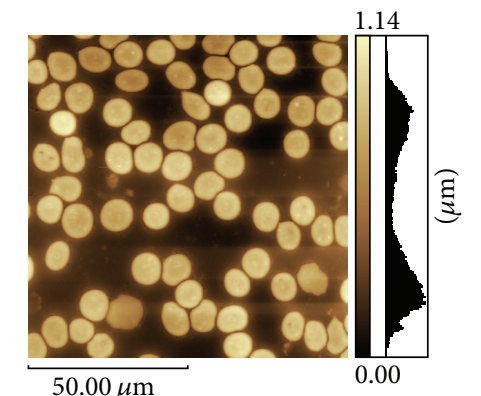

$100.00 \times 100.00 \mu \mathrm{m}$

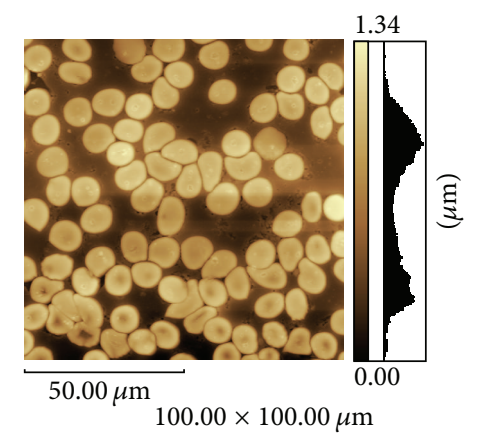

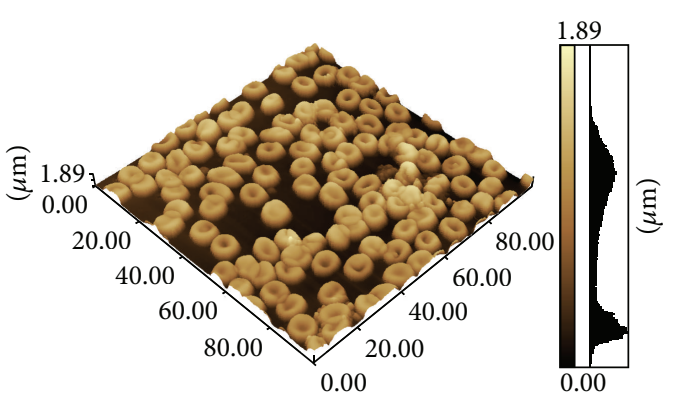

$100.00 \times 100.00(\mu \mathrm{m}) Z$ 0.00-1892.50 (nm)

(b)

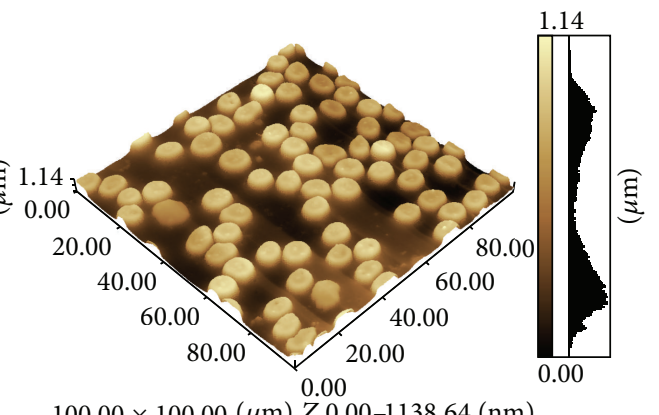

$100.00 \times 100.00(\mu \mathrm{m}) Z \quad 0.00-1138.64(\mathrm{~nm})$

(c)

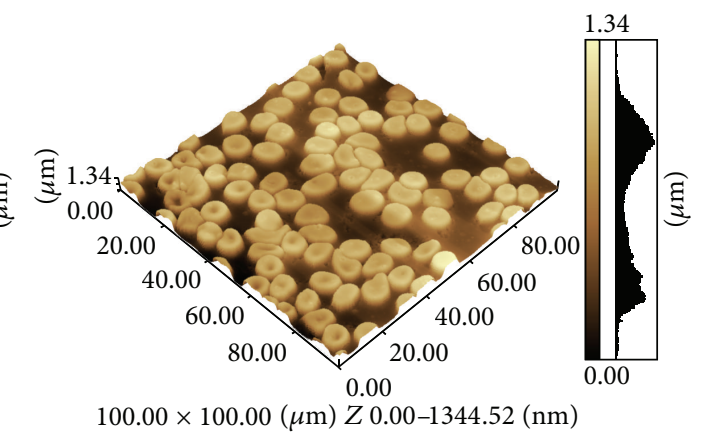

(d)

Figure 3: Human erythrocytes (type O) 2D and 3D images $(100 \times 100 \mu \mathrm{m})$ captured by atomic force microscopy. (a) Blood film treated with $1,000 \mu \mathrm{g} / \mathrm{mL}$ of Cry8Ka5 protein. (b) Blood film treated with $1,000 \mu \mathrm{g} / \mathrm{mL}$ of CrylAc protein. (c) Blood film treated with $1,000 \mu \mathrm{g} / \mathrm{mL}$ of bovine serum albumin. (d) Blood film untreated. Arrows indicate the visible presence of Cry proteins on the surface of the erythrocytes. 







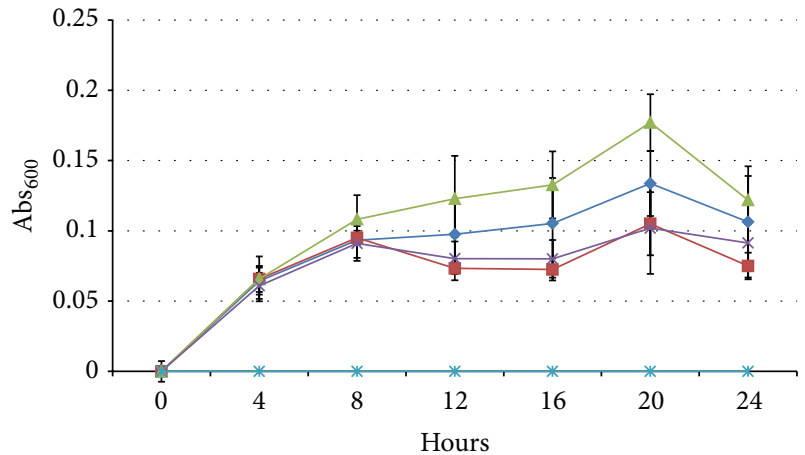

(a)

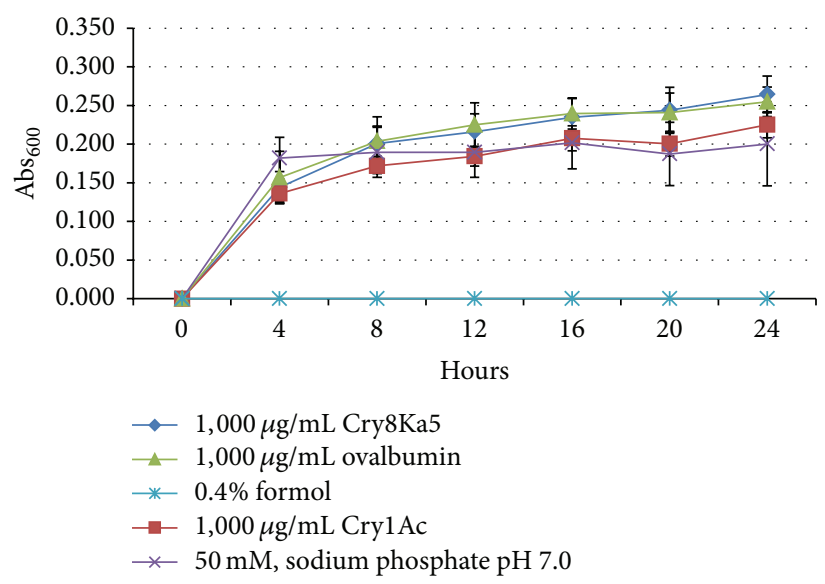

(c)



(b)



(d)

FIGURE 4: Growth curves of Gram-positive strains, (a) Bacillus subtilis and (b) Staphylococcus aureus, and Gram-negative bacteria, (c) Enterobacter aerogenes and (d) Salmonella choleraesuis, grown in nutrient broth containing the Cry8Ka5, CrylAc, and ovalbumin, all at a concentration of $1,000 \mu \mathrm{g} / \mathrm{mL}$, and non-protein controls, sodium $50 \mathrm{mM}$ phosphate buffer, $\mathrm{pH} 7.0$, and $0.4 \%$ formol. The coefficients of variation for each point were $\leq 10 \%$. For all readings $\mathrm{Abs}_{600}$, Cry8Ka5, and CrylAc showed no significant difference $(P>0.05$, one-way ANOVA) compared to the controls, ovalbumin, or $50 \mathrm{mM}$ sodium phosphate buffer, $\mathrm{pH}$ 7.0.

the proteins and control and with no treatment. In (A) and (B) you can view the Cry8Ka5 and CrylAc proteins, respectively, on the surface of erythrocytes or dispersed in the extracellular fluid. In addition, no visible abnormality or deformity can be found in erythrocytes treated with the proteins or when compared to those which were not exposed to any treatment.

3.5. Effects on Artemia sp. To contribute with further information to the cytotoxicity assessment, it was performed an alternative evaluation that uses Artemia nauplii. Cytotoxicity was estimated based on the occurrence of nauplii death. Then, Artemia nauplii $48 \mathrm{~h}$ old were exposed to Cry8Ka5, CrylAc, and bovine serum albumin proteins in various concentrations and also to the artificial seawater control for $24 \mathrm{~h}$.

In Table 4, it is possible to observe that the Cry8Ka5 protein showed $\mathrm{LC}_{50}$ of $755.11 \pm 86.88 \mu \mathrm{g} / \mathrm{mL}$, unique among the samples with $\mathrm{LC}_{50}$ lower than $1,000 \mu \mathrm{g} / \mathrm{mL}$ (highest concentration).

3.6. Effects on Microorganisms. Four bacterial strains, two Gram-positive (B. subtilis and S. aureus) and two Gramnegative (E. aerogenes and $S$. choleraesuis) and also four yeasts (C. albicans, C. tropicalis, P. anomala, and Saccharomyces cerevisiae) were exposed for 24 and $48 \mathrm{~h}$, respectively, at concentrations ranging from 30.6 to $1,000 \mu \mathrm{g} / \mathrm{mL}$ of Cry8Ka5, CrylAc, ovalbumin (negative protein control), $50 \mathrm{mM}$ sodium phosphate buffer $\mathrm{pH} 7.0$ (negative control), and $0.4 \%$ formol (positive control), to evaluate the effects of proteins on some microorganisms that comprise the microbiota of mammals or of those phylogenetically close. In Figure 4, it is presented the growth curves separately of each bacteria strains in the presence of the protein samples at the highest concentration tested $(1,000 \mu \mathrm{g} / \mathrm{mL})$. For each kind of bacteria, it is possible to observe a linearity of growth and a clear overlay $\left(P>0.05\right.$ for each reading at $\left.\mathrm{OD}_{600}\right)$ for each sample tested, except for the treatment with formol that resulted in no growth. Similarly, in Figure 5, it is shown separately the growth curves of each kind of yeast when exposed to the protein samples. It can be seen that the growth curve obeys linearity and an evident overlay between the curves $\left(P>0.05\right.$ for each reading at $\left.\mathrm{OD}_{600}\right)$, except in the treatment with formol in which no growth was observed at all. Consequently, the MIC of the protein samples was > $1,000 \mu \mathrm{g} / \mathrm{mL}$, in both bacteria and yeasts tested. 


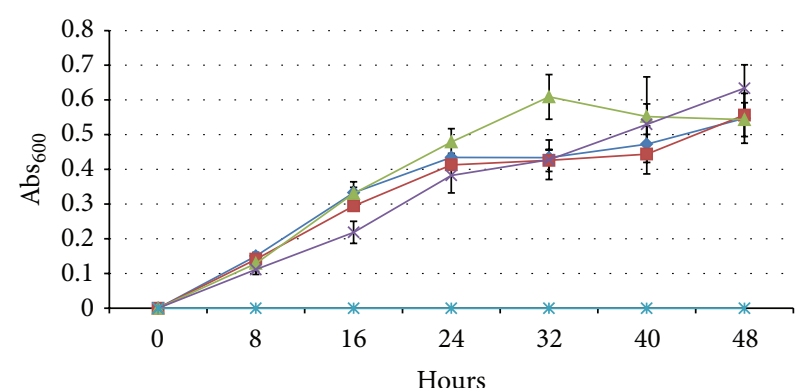

(a)

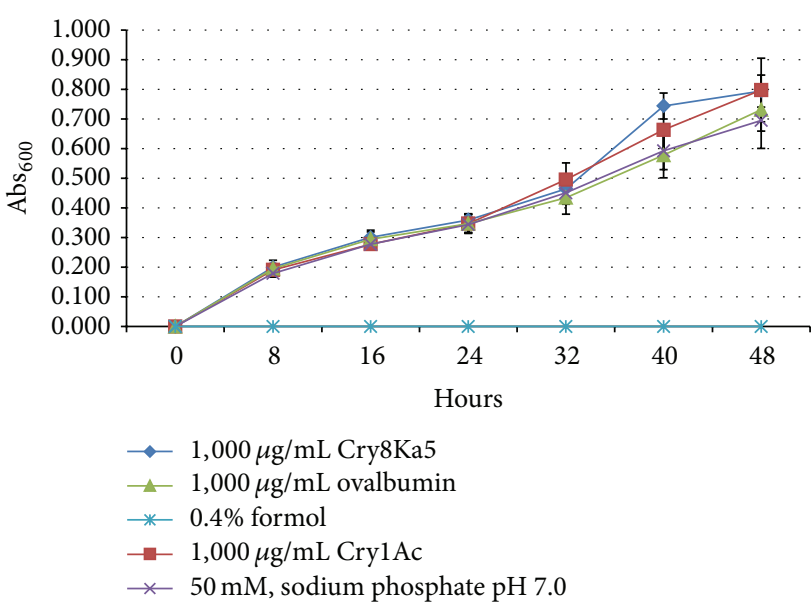

(c)



(b)

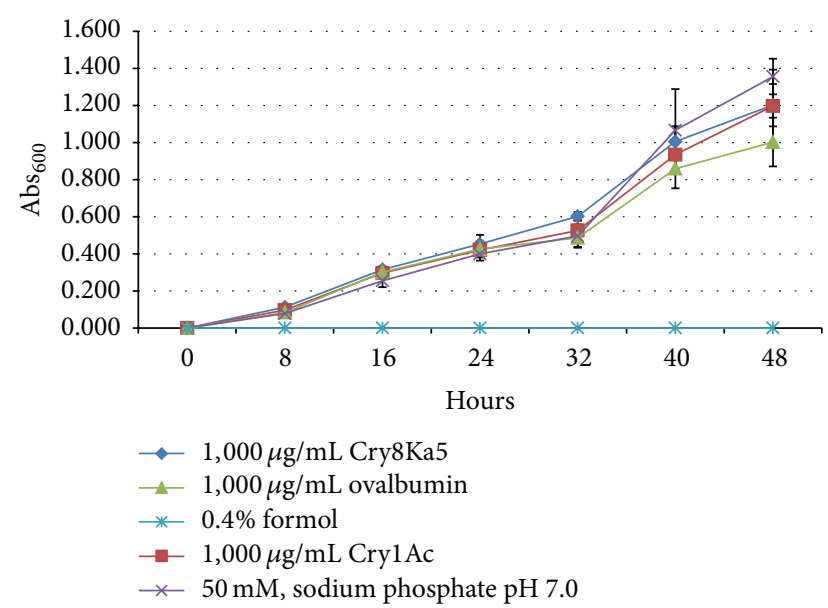

(d)

FIGURE 5: Growth curves of the yeast (a) Candida albicans, (b) C. tropicalis, (c) Pichia anomala, and (d) Saccharomyces cerevisiae grown in BHI broth, $\mathrm{pH}$ 5.0, containing Cry8Ka5, CrylAc, and ovalbumin proteins, all in concentration of 1,000 $\mu \mathrm{g} / \mathrm{mL}$, and nonprotein controls, $0.05 \mathrm{M}$ sodium phosphate buffer, $\mathrm{pH} 7.0$, and $0.4 \%$ formol. The coefficients of variation for each point were $\leq 10 \%$. For all readings $\mathrm{Abs} 600$, Cry8Ka5, and CrylAc showed no significant difference $(P>0.05$, ANOVA) compared to the controls, ovalbumin, or $50 \mathrm{mM}$ sodium phosphate buffer, $\mathrm{pH} 7.0$.

TABLE 3: One-dimensional, two-dimensional, and three-dimensional parameters of erythrocytes morphology treated with Cry8Ka5, CrylAc, or bovine serum albumin at a concentration of $1,000 \mu \mathrm{g} / \mathrm{mL}$ measured by atomic force microscopy.

\begin{tabular}{lcccc}
\hline Parameters & Cry8Ka5 & CrylAc & Bovine Serum albumin & Untreated $^{\mathrm{g}}$ \\
\hline Standard width $(\mu \mathrm{m})$ & $9.71 \pm 1.17^{\mathrm{abc}}$ & $8.62 \pm 0.92$ & $8.44 \pm 0.94$ & $8.48 \pm 0.82$ \\
Perimeter $(\mu \mathrm{m})$ & $33.15 \pm 3.59^{\mathrm{abc}}$ & $28.68 \pm 1.86$ & $28.45 \pm 2.08$ & $29.42 \pm 2.20$ \\
Average $Z(\mu \mathrm{m})$ & $0.76 \pm 0.08^{\mathrm{ac}}$ & $1.18 \pm 0.14^{\mathrm{de}}$ & $0.78 \pm 0.07^{\mathrm{f}}$ & $1.00 \pm 0.12$ \\
Area excluding voids $\left(\mu \mathrm{m}^{2}\right)$ & $72.97 \pm 12.15^{\mathrm{abc}}$ & $58.48 \pm 7.66$ & $58.36 \pm 7.95$ & $61.08 \pm 7.92$ \\
Area including voids $\left(\mu \mathrm{m}^{2}\right)$ & $73.74 \pm 11.45^{\mathrm{abc}}$ & $58.43 \pm 7.66$ & $58.38 \pm 7.66$ & $61.16 \pm 7.84$ \\
Surface area $\left(\mu \mathrm{m}^{2}\right)$ & $74.96 \pm 12.58^{\mathrm{abc}}$ & $61.83 \pm 8.12$ & $59.36 \pm 8.01$ & $62.24 \pm 8.04$ \\
Volume $\left(\mu \mathrm{m}^{3}\right)$ & $55.94 \pm 10.72^{\mathrm{abc}}$ & $69.56 \pm 14.46^{\mathrm{de}}$ & $45.66 \pm 7.04^{\mathrm{f}}$ & $61.45 \pm 10.70$ \\
\hline
\end{tabular}

Values are means \pm standard deviations of 100 measures; ${ }^{\mathrm{a}} P<0.05$ (one-way ANOVA) for Cry8Ka5 compared to CrylAc; ${ }^{\mathrm{b}} P<0.05$ (one-way ANOVA) for Cry8Ka5 compared to bovine serum albumin; ${ }^{\mathrm{c}} P<0.05$ (one-way ANOVA) for Cry8Ka5 compared to untreated; ${ }^{\mathrm{d}} P<0.05$ (one-way ANOVA) for CrylAc compared to bovine serum albumin; ${ }^{\mathrm{e}} P<0.05$ (one-way ANOVA) for CrylAc compared to untreated; ${ }^{\mathrm{f}} P<0.05$ (one-way ANOVA) to bovine serum albumin compared to untreated.

${ }^{\mathrm{g}}$ Erythrocytes not exposed to treatment.

\section{Discussion}

Even though the current GMO safety assessments seem to be efficient, several studies have pointed out failures or gaps in these procedures regarding noncoverage of important issues such as the evaluation of effects on cells of nontarget organisms (e.g., mammalian cells) and on the microbiota of the GMO consumer organism [15-18]. In this context, this study aimed to evaluate the Cry $8 \mathrm{Ka} 5$ mutant protein and the CrylAc protein on their cyto- and genotoxic effects upon 
TABle 4: Cytotoxicity evaluation of Cry8Ka5, CrylAc, and protein and nonprotein controls against Artemia sp. nauplii after $24 \mathrm{~h}$ exposure.

\begin{tabular}{lccc}
\hline Samples & Concentrations $(\mu \mathrm{g} / \mathrm{mL})$ & Mortality $(\%)^{\mathrm{a}}$ & $\mathrm{LC}_{50}{ }^{\mathrm{b}}(\mu \mathrm{g} / \mathrm{mL})$ \\
\hline & 1,000 & 66.67 & $755.11 \pm 86.88$ \\
Cry8Ka5 & 500 & 26.67 & $(623.93-978.60)^{\mathrm{c}}$ \\
& 250 & 6.67 & 0 \\
\hline CrylAc & 125 & 10 & $>1,000$ \\
\hline Bovine serum albumin & 1,000 & 3.33 & $>1,000$ \\
\hline Artificial seawater & 1,000 & 0 & - \\
\hline Temephos ${ }^{\mathrm{d}}$ & - & - & 0.16 \\
\hline${ }^{\mathrm{a}}$ Values are means of triplicate for each sample. The standard deviations were less than 5\% of means; ${ }^{\mathrm{b}}$ Sample concentration capable of killing 50\% of Artemia
\end{tabular}

human lymphocytes, the presence of damage in erythrocytes of three mammalian species, cytotoxicity to Artemia sp., and antimicrobial effects.

Tests to assess the cytotoxic and genotoxic effects in peripheral lymphocytes of healthy humans have been extensively used for safety evaluation of natural and synthetic compounds present in high concentrations in foods and in the environment as contaminants or for the evaluation of new specific molecules with anticancer potential [27, 34]. Even at the highest concentration tested $(1,000 \mu \mathrm{g} / \mathrm{mL})$, the CrylAc and Cry8Ka5 did not show any cytotoxic effects on lymphocytes. Likewise, these proteins at a concentration of $1,000 \mu \mathrm{g} / \mathrm{mL}$ did not cause any lymphocyte DNA damage, showing no genotoxic effects according to the method used. Shimada et al. [35] and Bondzio et al. [18] also did not detect cytotoxic effects of the toxin CrylAb in bovine hepatocytes culture and epithelial cells culture from ovine rumen, respectively. Other Cry toxins, such as Cry4a and CryllA did not show cytotoxic effects against human breast carcinoma line MCF-7 [36].

Studies addressing the effects of Cry proteins on the genetic material of healthy cells are extremely rare. However, Grisolia et al. [37] reported genotoxic effects in zebrafish larvae and embryos (a model for this type of study) in the presence of moderate doses $(25-150 \mu \mathrm{g} / \mathrm{mL})$ of CrylAa, Cry1Ab, CrylAc, and Cry2A proteins separately or in combinations. The absence of cytotoxic and genotoxic effects of the Cry proteins tested on human lymphocytes can be reasonably explained by the lack of receptors for effective binding of these proteins to the surface of this kind of cells [38]. It is also worth noting that the evaluation of cyto- and genotoxicity in human lymphocytes with Cry proteins performed in this study is the first example of the use of these tests for the safety assessment of $B t$ toxins.

The effect of Cry8Ka5 and CrylAc toxins on the integrity of the erythrocytes membrane of rabbit, rat, and humans (types $\mathrm{A}, \mathrm{B}, \mathrm{AB}$, and $\mathrm{O}$ ) was also investigated. The reason for this is that the erythrocytes are the most abundant cells in various species of animals of the phylum chordata and are subject to various cytotoxic molecules, including proteins, called hemolysins. Thus, two tests were performed, the classic hemolytic activity in erythrocyte suspension (2\%) and the erythrocyte cell membrane topography analysis in whole human blood (type O). In the evaluation of hemolytic activity, all suspensions of erythrocytes from different origins did not show hemolysis percentage higher than $1 \%$ when exposed to the highest concentration of Cry8Ka5 $(1,000 \mu \mathrm{g} / \mathrm{mL})$. On the other hand, CrylAc protein showed percentage values of hemolytic activity at the highest concentration $(1,000 \mu \mathrm{g} / \mathrm{mL})$ towards different erythrocyte samples, which ranged from 4.6 to $16.6 \%$. However, according to the criteria of Bernheimer [29], results lower than $20 \%$ must be considered irrelevant given that certain animal species have inherent propensity of erythrocyte hemolysis.

Although the hemolytic activity test provides valuable results in the context of a safety assessment of a recombinant protein, not all harmful substances to cells cause severe cell membrane injury that culminate in disruption of the cell membrane and release of hemoglobin. Often, the damage to the membrane may be due to the low concentration of potentially cytotoxic molecule or on account of low affinity for membrane receptors. Such circumstances may lead to a slight loss of cell content or swelling due to slow influx of external fluid, in both cases, causing deformities in the cell. Therefore, the cellular membrane topography by AFM analysis can contribute with information about the integrity of the erythrocyte membrane exposed to Cry proteins. In the case of the exposure of human erythrocytes (type O) to Cry $8 \mathrm{Ka} 5$ protein compared to native erythrocytes (untreated), differences were observed in the seven parameters. Even though these differences were significant from a statistical standpoint, the changes promoted by Cry $8 \mathrm{Ka} 5$ were not too pronounced, and the average values of the parameters of this treatment were only 0.1 to 0.24 times larger or smaller than the values of the group not treated. The magnitude of this difference is not easy to explain, but it certainly was not able to promote hemolysis of the cells, even at a concentration where it is unlikely that a nontarget cell would be exposed. Another point worth mentioning is that all samples differed from the untreated group in the volume parameter which is perhaps the most important parameter because it provides clear signs of a possible influx of fluid into the cell given the hypotonic condition of the medium. Depending on the period of exposure to the treatment, this could lead to cell lysis. The possibility of using cell membrane topography analysis via AFM was initially raised by Brand et al. [39], 
who showed marked changes in the erythrocyte membrane parameters caused by treatment with dermaseptins, which are cytotoxic peptides isolated from the skin of the frog Phyllomedusa hypochondrialis. Another interesting fact is that it is possible to see clearly from the images in $2 \mathrm{D}$ and $3 \mathrm{D}$ the accumulation of Cry proteins, especially Cry8Ka5, on the erythrocytes surface. If there was any interaction of Cry proteins with membrane receptors, it was not able to unleash their classic effects of pore formation in the same magnitude that occurs in the midgut cells of target insects. In general, the proteins tested did not cause severe damage to erythrocytes, neither with hemolysis nor with pronounced alterations in the membrane.

Still in the context of the cytotoxicity assessing of Cry8Ka5 and CrylAc proteins, the survival rate of Artemia sp. nauplii was evaluated. The genus Artemia (Crustacea, Branchiopoda, and Anostraca), especially the species Artemia salina and A. franciscana, is used in a wide range of toxicological tests and research [40-42]. Since it is a low cost, fast, and very informative test and does not bring up ethical issues (because it does not inflict suffering to vertebrates), it was employed in this study. The CrylAc protein showed very high $\mathrm{LC}_{50}(>1,000 \mu \mathrm{g} / \mathrm{mL})$, while the Cry8Ka5 showed lower value $(755.11 \mu \mathrm{g} / \mathrm{mL})$. However, if we consider the $\mathrm{LC}_{50}$ of Cry8Ka5 to its main target, the cotton boll weevil $(2.83 \mu \mathrm{g} / \mathrm{mL}$, according to Oliveira et al. [6]), we would conclude that the value found against Artemia is almost 270 times greater, which only reinforces the specificity of this protein. Moreover, hardly a nontarget organism would be exposed to Cry8Ka5 in such high concentration. Therefore, the results of the cytotoxicity assay with Artemia sp. corroborate the results of other tests performed with Cry8Ka5 but showed greater sensitivity to potential toxic effects of this molecule. This suggests the need of further testing with a larger number of different Cry molecules to confirm the potential of this microcrustacean as a biomarker for evaluating new $B t$ proteins.

One of the main questions about the effectiveness of the current methods for the safety assessment of recombinant proteins is the absence of tests that evaluate the impact of these molecules on the microbiota of mammals' gastrointestinal tract [18]. Also, there is a concern about the effects of these proteins on soil microorganisms, given the importance of maintaining the balance of ecosystems $[43,44]$. In this context, we selected four bacteria and four yeasts, all common to human and animal microbiota, to assess the antimicrobial effects of the experimental proteins. Both CrylAc and Cry8Ka5 proteins showed no growth inhibition in liquid medium neither to the Gram-positive and Gram-negative bacteria nor to yeasts at a concentration of $1,000 \mu \mathrm{g} / \mathrm{mL}$. In fact, most reports of antibacterial activity of $B t$ proteins are related to the classes of Cry proteins with mosquitocidal activity, that is, Cry proteins with activity against Diptera $[15,16]$, which is not the case of the Cry proteins under study. Nevertheless, for some Cry toxins active against other classes of insects (such as CrylAb, CrylD, and Cry3Aa), there are reports of antimicrobial effects against aerobic and anaerobic bacteria, with MICs ranging from 45 to $150 \mu \mathrm{g} / \mathrm{mL}$ and with mechanisms of action related to the composition of the cell wall [17]. Hence, the absence of antibacterial activity of the
Cry toxins tested may be related to cell wall composition of the strains used. As to the absence of antifungal activity of the Cry proteins, the composition of the fungal cell wall formed mainly of chitin and nonspecific binding sites for these proteins may explain the negative results obtained against fungi. Indeed, the absence of cytotoxic and genotoxic effects in mammalian cells and the negative effects on the microorganisms' growth are extremely positive characteristics in the context of Cry8Ka5 and CrylAc proteins safety assessment.

\section{Conclusions}

In conclusion, the Cry8Ka5 and CrylAc proteins showed no significant cytotoxicity or genotoxicity, even when tested at high doses under different methodologies, and have not shown antimicrobial activity against the tested microorganisms. Moreover, the methods employed in this study contributed with valuable information on the effects of Cry8Ka5 and CrylAc proteins on nontarget organisms, enhancing their potential for safe biotechnological applications. In addition, these assays could be also used to gather safety information on other Cry proteins beyond those obtained in the current safety assessment approach.

\section{Conflict of Interests}

The authors declare that there is no conflict of interests regarding the publication of this paper.

\section{Acknowledgments}

The authors thank Conselho Nacional de Desenvolvimento Científico e Tecnológico (CNPq) (Edital MCT/ CNPq/CTAGRO No. 43/2009-Bicudo) and Coordenação de Aperfeiçoamento de Pessoal do Ensino Superior (CAPES) (Edital No. 71/2013 Programa Ciências Sem FronteirasPesquisador Visitante Especial-Linha 1) for financial support of this research.

\section{References}

[1] D. L. Prieto-Samsonov, R. I. Vázquez-Padrón, C. Ayra-Pardo, J. González-Cabrera, and G.A. de la Riva, "Bacillus thuringiensis: from biodiversity to biotechnology," Journal of Industrial Microbiology and Biotechnology, vol. 19, pp. 202-219, 1997.

[2] J. Mendelsohn and J. Baselga, "Status of epidermal growth factor receptor antagonists in the biology and treatment of cancer," Journal of Clinical Oncology, vol. 21, no. 14, pp. 2787-2799, 2003.

[3] J. Romeis, M. Meissle, and F. Bigler, "Transgenic crops expressing Bacillus thuringiensis toxins and biological control," Nature Biotechnology, vol. 24, no. 1, pp. 63-71, 2006.

[4] A. M. R. Gatehouse, N. Ferry, M. G. Edwards, and H. A. Bell, "Insect-resistant biotech crops and their impacts on beneficial arthropods," Philosophical Transactions of the Royal Society B: Biological Sciences, vol. 366, no. 1569, pp. 1438-1452, 2011.

[5] G. Sanahuja, R. Banakar, R. M. Twyman, T. Capell, and P. Christou, "Bacillus thuringiensis: a century of research, development 
and commercial applications," Plant Biotechnology Journal, vol. 9, no. 3, pp. 283-300, 2011.

[6] G. R. Oliveira, M. C. Silva, W. A. Lucena et al., "Improving Cry8Ka toxin activity towards the cotton boll weevil (Anthonomus grandis)," BMC Biotechnology, vol. 11, article 85, 2011.

[7] B. Delaney, J. D. Astwood, H. Cunny et al., "Evaluation of protein safety in the context of agricultural biotechnology," Food and Chemical Toxicology, vol. 46, pp. S71-S97, 2008.

[8] M. O'Callaghan, T. R. Glare, E. P. J. Burgess, and L. A. Malone, "Effects of plants genetically modified for insect resistance on nontarget organisms," Annual Review of Entomology, vol. 50, pp. 271-292, 2005.

[9] H. Yu, Y. Li, and K. Wu, "Risk assessment and ecological effects of transgenic Bacillus thuringiensis crops on non-target organisms," Journal of Integrative Plant Biology, vol. 53, no. 7, pp. 520-538, 2011.

[10] H. P. J. M. Noteborn, M. E. Bienenmann-Ploum, J. H. J. van den Berg et al., "Safety assessment of the Bacillus thuringiensis insecticidal crystal protein CRYIA(b) expressed in tomato," in Genetically Modified Foods: Safety Issues, G. R. Takeoko, R. Teranishi, and K. H. Engel, Eds., pp. 23-26, American Chemical Society, Washington, DC, USA, 1996.

[11] M. Gill and D. Ellar, "Transgenic Drosophila reveals a functional in vivo receptor for the Bacillus thuringiensis toxin CrylAcl," Insect Molecular Biology, vol. 11, no. 6, pp. 619-625, 2002.

[12] N. A. Broderick, K. F. Raffa, and J. Handelsman, "Midgut bacteria required for Bacillus thuringiensis insecticidal activity," Proceedings of the National Academy of Sciences of the United States of America, vol. 103, no. 41, pp. 15196-15199, 2006.

[13] H.-S.. Kim, S. Yamashita, T. Akao et al., "In vitro cytotoxicity of non-Cyt inclusion proteins of a Bacillus thuringiensis isolate against human cells, including cancer cells," Journal of Applied Microbiology, vol. 89, no. 1, pp. 16-23, 2000.

[14] R. Mesnage, E. Clair, S. Gress, C. Then, A. Székács, and G.-E. Séralini, "Cytotoxicity on human cells of CrylAb and CrylAc Bt insecticidal toxins alone or with a glyphosate-based herbicide," Journal of Applied Toxicology, vol. 33, no. 7, pp. 695-699, 2013.

[15] T. G. Yudina, A. V. Konukhova, L. P. Revina, L. I. Kostina, I. A. Zalunin, and G. G. Chestukhina, "Antibacterial activity of Cryand Cyt-proteins from Bacillus thuringiensis ssp. israelensis," Canadian Journal of Microbiology, vol. 49, no. 1, pp. 37-44, 2003.

[16] L. P. Revina, L. I. Kostina, M. A. Dronina et al., "Novel antibacterial proteins from entomocidal crystals of Bacillus thuringiensis ssp. israelensis," Canadian Journal of Microbiology, vol. 51, no. 2, pp. 141-148, 2005.

[17] T. G. Yudina, A. L. Brioukhanov, I. A. Zalunin et al., "Antimicrobial activity of different proteins and their fragments from Bacillus thuringiensis parasporal crystals against clostridia and archaea," Anaerobe, vol. 13, no. 1, pp. 6-13, 2007.

[18] A. Bondzio, F. Stumpff, J. Schön, H. Martens, and R. Einspanier, "Impact of Bacillus thuringiensis toxin CrylAb on rumen epithelial cells (REC) - a new in vitro model for safety assessment of recombinant food compounds," Food and Chemical Toxicology, vol. 46, no. 6, pp. 1976-1984, 2008.

[19] A. Bondzio, U. Lodemann, C. Weise, and R. Einspanier, "CrylAb treatment has no effects on viability of cultured porcine intestinal cells, but triggers Hsp70 expression," PLoS ONE, vol. 8, no. 7, Article ID e67079, 2013.

[20] M. M. Bradford, "A rapid and sensitive method for the quantitation of microgram quantities of protein utilizing the principle of protein dye binding," Analytical Biochemistry, vol. 72, no. 1-2, pp. 248-254, 1976.
[21] U. K. Laemmli, "Cleavage of structural proteins during the assembly of the head of bacteriophage T4," Nature, vol. 227, no. 5259, pp. 680-685, 1970.

[22] M. F. Grossi-de-Sa, M. Q. de Magalhães, M. S. Silva et al., "Susceptibility of Anthonomus grandis (cotton boll weevil) and Spodoptera frugiperda (fall armyworm) to a Crylla-type toxin from a Brazilian Bacillus thuringiensis strain," Journal of Biochemistry and Molecular Biology, vol. 40, no. 5, pp. 773-782, 2007.

[23] P. Edman, "Determination of amino acid sequences in protein," Thrombosis et Diathesis Haemorrhagica, supplement 13, pp. 1720, 1964.

[24] R. V. Burim, R. Canalle, J. L. C. Lopes, W. Vichnewski, and C. S. Takahashi, "Genotoxic action of the sesquiterpene lactone centratherin on mammalian cells in vitro and in vivo," Teratogenesis, Carcinogenesis, and Mutagenesis, vol. 21, no. 6, pp. 383-393, 2001.

[25] T. Mosmann, "Rapid colorimetric assay for cellular growth and survival: application to proliferation and cytotoxicity assays," Journal of Immunological Methods, vol. 65, no. 1-2, pp. 55-63, 1983.

[26] T. M. Souza, D. F. Farias, B. M. Soares et al., "Toxicity of Brazilian plant seed extracts to two strains of Aedes aegypti (Diptera: Culicidae) and nontarget animals," Journal of Medical Entomology, vol. 48, no. 4, pp. 846-851, 2011.

[27] P. D. L. Lima, D. S. Leite, M. C. Vasconcellos et al., "Genotoxic effects of aluminum chloride in cultured human lymphocytes treated in different phases of cell cycle," Food and Chemical Toxicology, vol. 45, no. 7, pp. 1154-1159, 2007.

[28] M. P. Merker and L. Levine, "A protein from the marine mollusc Aplysia californica that is hemolytic and stimulates arachidonic acid metabolism in cultured mammalian cells," Toxicon, vol. 24, no. 5, pp. 451-465, 1986.

[29] A. W. Bernheimer, "Assay of hemolytic toxins," Methods in Enzymology, vol. 165, pp. 213-217, 1988.

[30] L. V. Costa-Lotufo, M. T. Khan, A. Ather et al., "Studies of the anticancer potential of plants used in Bangladeshi folk medicine," Journal of Ethnopharmacology, vol. 13, pp. 21-30, 2005.

[31] D. J. Finney, Probit Analysis, Cambridge University Press, Cambridge, UK, 3rd edition, 1971.

[32] D. C. Hissa, I. M. Vasconcelos, A. F. U. Carvalho et al., "Novel surfactant proteins are involved in the structure and stability of foam nests from the frog Leptodactylus vastus," Journal of Experimental Biology, vol. 211, no. 16, pp. 2707-2711, 2008.

[33] S. F. F. Ribeiro, A. P. Agizzioa, O. L. T. Machado et al., "A new peptide of melon seeds which shows sequence homology with vicilin: partial characterization and antifungal activity," Scientia Horticulturae, vol. 111, pp. 399-405, 2007.

[34] G. C. G. Militão, I. N. F. Dantas, P. M. P. Ferreira et al., "In vitro and in vivo anticancer properties of cucurbitacin isolated from Cayaponia racemosa," Pharmaceutical Biology, vol. 50, no. 12, pp. 1479-1487, 2012.

[35] N. Shimada, Y. S. Kim, K. Miyamoto, M. Yoshioka, and H. Murata, "Effects of Bacillus thuringiensis CrylAb toxin on mammalian cells," Journal of Veterinary Medical Science, vol. 65, no. 2, pp. 187-191, 2003.

[36] R. F. T. Corrêa, D. M. P. Ardisson-Araújo, R. G. Monnerat, and B. M. Ribeiro, "Cytotoxicity analysis of three Bacillus thuringiensis subsp. israelensis $\delta$-endotoxins towards insect and mammalian cells," PLoS ONE, vol. 7, no. 9, Article ID e46121, 2012. 
[37] C. K. Grisolia, R. Oliveira, I. Domingues, E. C. Oliveira-Filho, R. G. Monerat, and A. M. V. M. Soares, "Genotoxic evaluation of different $\delta$-endotoxins from Bacillus thuringiensis on zebrafish adults and development in early life stages," Mutation Research, vol. 672, no. 2, pp. 119-123, 2009.

[38] A. Bravo, S. S. Gill, and M. Soberón, "Mode of action of Bacillus thuringiensis Cry and Cyt toxins and their potential for insect control," Toxicon, vol. 49, no. 4, pp. 423-435, 2007.

[39] G. D. Brand, J. R. S. A. Leite, L. P. Silva et al., "Dermaseptins from Phyllomedusa oreades and Phyllomedusa distincta: antiTrypanosoma cruzi activity without cytotoxicity to mammalian cells," The Journal of Biological Chemistry, vol. 277, no. 51, pp. 49332-49340, 2002.

[40] R. A. Acey, S. Bailey, P. Healy, C. Jo, T. F. Unger, and R. A. Hudson, "A butyrylcholinesterase in the early development of the brine shrimp (Artemia salina) larvae: a target for phthalate ester embryotoxicity?" Biochemical and Biophysical Research Communications, vol. 299, no. 4, pp. 659-662, 2002.

[41] M. Favilla, L. Macchia, A. Gallo, and C. Altomare, "Toxicity assessment of metabolites of fungal biocontrol agents using two different (Artemia salina and Daphnia magna) invertebrate bioassays," Food and Chemical Toxicology, vol. 44, no. 11, pp. 1922-1931, 2006.

[42] Z. A. Mohamed, "First report of toxic Cylindrospermopsis raciborskii and Raphidiopsis mediterranea (Cyanoprokaryota) in Egyptian fresh waters," FEMS Microbiology Ecology, vol. 59, no. 3, pp. 749-761, 2007.

[43] K. R. Prihoda and J. R. Coats, "Aquatic fate and effects of Bacillus thuringiensis Cry3Bb1 protein: toward risk assessment," Environmental Toxicology and Chemistry, vol. 27, no. 4, pp. 793-798, 2008.

[44] K. R. Prihoda and J. R. Coats, "Fate of Bacillus thuringiensis (Bt) Cry3Bb1 protein in a soil microcosm," Chemosphere, vol. 73, no. 7, pp. 1102-1107, 2008. 

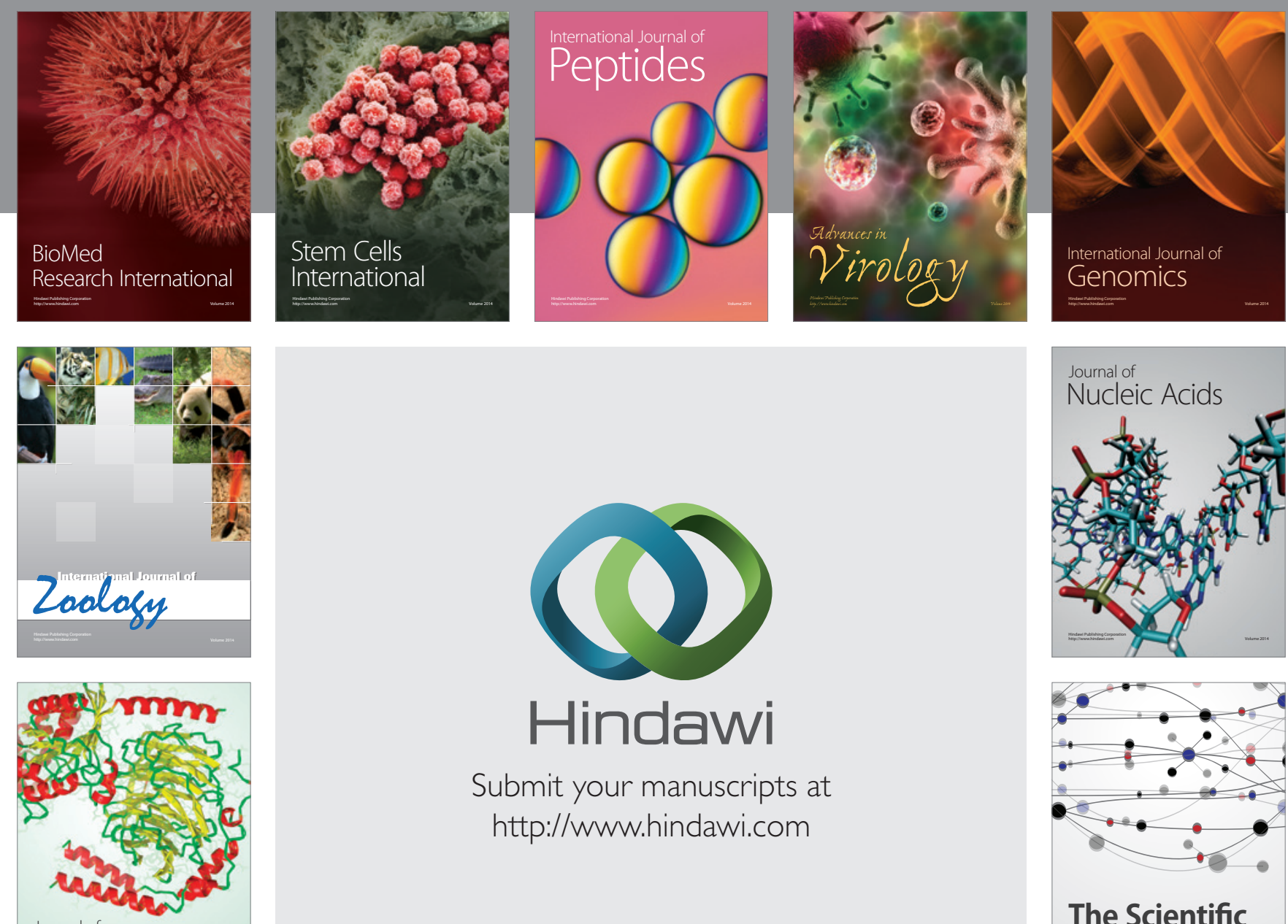

Submit your manuscripts at

http://www.hindawi.com

Journal of
Signal Transduction
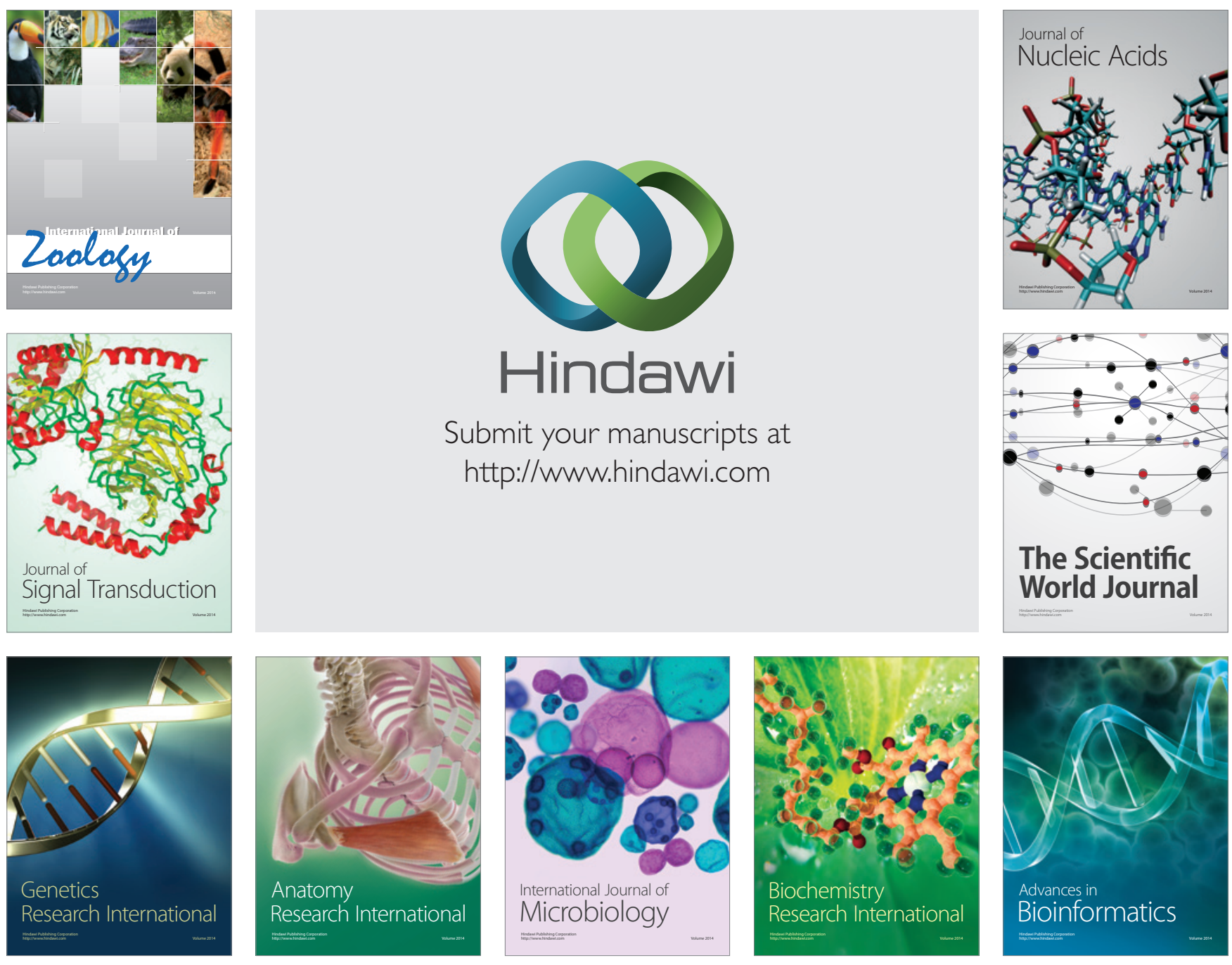

The Scientific World Journal
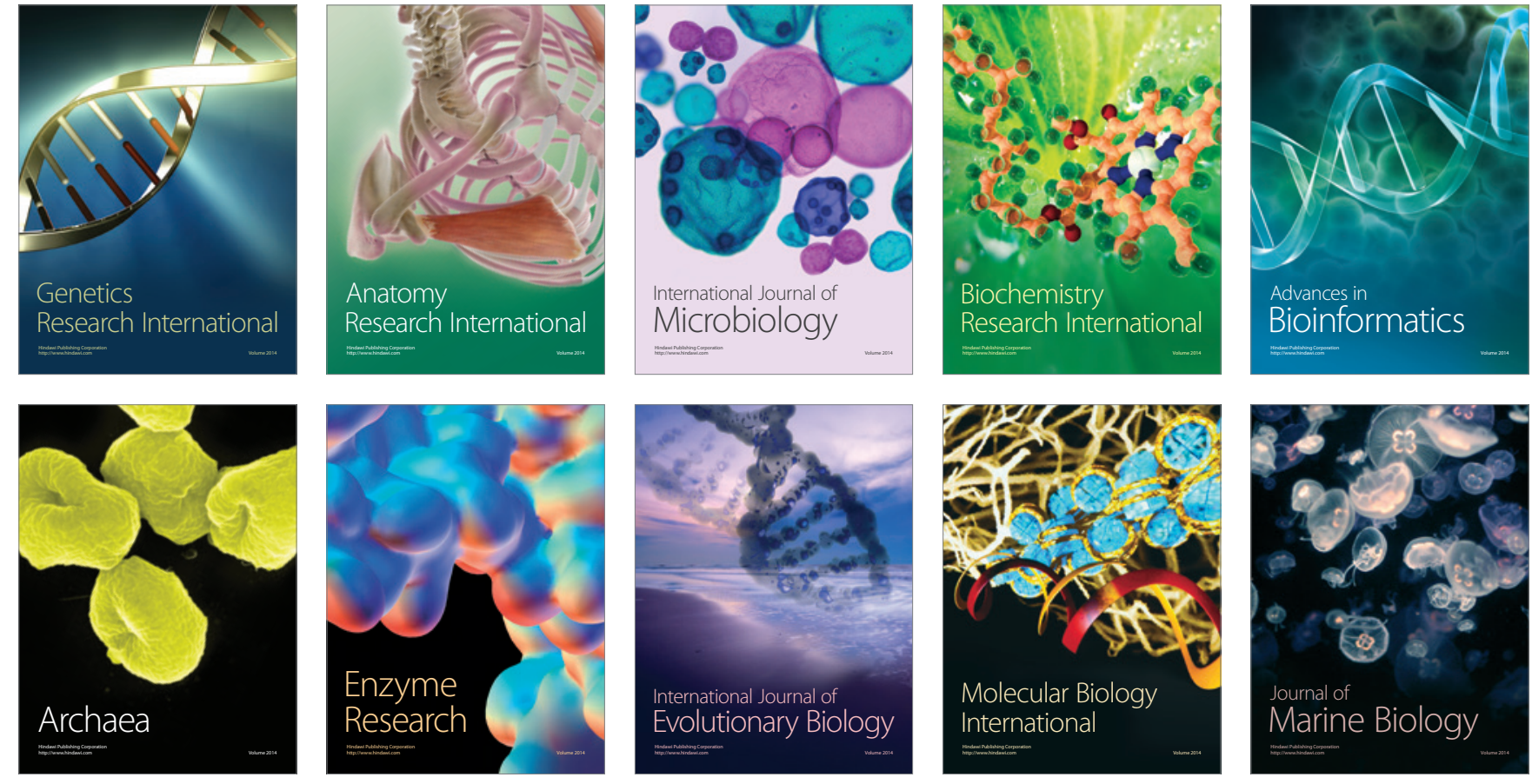